\title{
Pengaruh inflasi, investasi asing langsung dan pengeluaran pemerintah terhadap pertumbuhan ekonomi Indonesia
}

\author{
Riris Prantika Putri*; Heriberta; Emilia \\ Prodi Ekonomi Pembangunan Fakultas Ekonomi dan Bisnis Univ. Jambi \\ *E-mail korespondensi:Ririsprantikap@gmail.com
}

\begin{abstract}
This study aims to analyze the development of inflation, foreign direct investment (FDI) and government expenditure to economic growth in Indonesia also to identify and analyze the effect of inflation, FDI and government expenditure to economic growth in Indonesia. The data used is secondary data in the form of time series. Based on the data obtained, the average development of economic growth in Indonesia during the period 2000-2017 was 5.29\%. Based on the F test the independent variables tend to influence the dependent variable. In the t-test is known that inflation does not affect the economic growth in Indonesia, while FDI and government expenditure has a positive and significant impact on economic growth in Indonesia. The $R^{2}$ value is 0,594602, amounting to $59.46 \%$ means that economic growth is affected by inflation, FDI and government expenditure, $40.54 \%$ influenced by other factors that were not included in this study.
\end{abstract}

Keywords: Economic growth, Inflation, Foreign Direct Investment (FDI), Government expenditure

\begin{abstract}
Abstrak
Penelitian ini bertujuan untuk menganalisis perkembangan inflasi, investasi asing langsung (FDI) dan pengeluaran pemerintah terhadap pertumbuhan ekonomi Indonesia serta untuk mengetahui dan menganalisis pengaruh inflasi, FDI dan pengeluaran pemerintah terhadap pertumbuhan ekonomi Indonesia. Data yang digunakan adalah data sekunder dalam bentuk time series. Berdasarkan data yang diperoleh, rata-rata perkembangan pertumbuhan ekonomi Indonesia selama periode 2000-2017 adalah sebesar 5,29\%. Berdasarkan uji $\mathrm{F}$ variable independen cenderung berpengaruh terhadap variable dependen. Dalam uji t diketahui bahwa inflasi tidak berpengaruh terhadap pertumbuhan ekonomi Indonesia, sedangkan FDI dan pengeluaran pemerintah berpengaruh positif dan signifikan terhadap pertumbuhan ekonomi Indonesia. Nilai $R^{2}$ sebesar 0,594602, artinya sebesar 59,46\% pertumbuhan ekonomi di pengaruhi oleh inflasi, FDI dan pengeluaran pemerintah, 40,54 \% di pengaruhi oleh faktor lain yang tidak dimasukkan dalam penelitian ini.
\end{abstract}

Kata kunci: Pertumbuhan ekonomi, Inflasi, Investasi asing langsung, Pengeluaran pemerintah

\section{PENDAHULUAN}

Indonesia menjadi salah satu Negara berkembang yang memiliki tingkat pertumbuhan ekonomi yang tinggi. Emerging market (pasar modal di Negara 
berkembang) selalu berhasil menarik investor untuk masuk dan melakukan diversifikasi internasional, salah satunya Indonesia. Pertumbuhan ekonomi di Negara berkembang memiliki karakteristik yang berbeda dengan pasar di Negara maju, sehingga akan lebih menguntungkan dalam membentuk investasi di Negara berkembang (Tandelilin, 2010). Pembangunan ekonomi dalam sebuah negara, pada dasarnya bertujuan untuk mencapai kemakmuran masyarakat melalui pertumbuhan ekonomi yang tinggi, dan diantara pembangunan ekonomi tersebut terdapat keterkaitan antara pembangunan nasional dan regional yang saling erat, sehingga membentuk perekonomian yang kokoh, kuat, dan merata. Adanya pertumbuhan ekonomi merupakan indikasi keberhasilan pembangunan ekonomi yang telah dicapai olehs ektor ekonomi tersebut pada suatu periode waktu tertentu. Menurut (Utami, 2012) pertumbuhan ekonomi juga menunjukkan sejauh mana aktivitas perekonomian dapat meningkatkan pendapatan masyarakat dalam kurun waktu tertentu, karena umumnya aktivitas perekonomian adalah suatu proses penggunaan faktor-faktor produksi untuk menghasilkan output, sehingga pada saat nya nanti akan memberikan suatu balas jasa terhadap faktor produksi yang dimiliki oleh masyarakat sebagai pemilik factor produksi.

Menurut Samuelson (2013), pertumbuhan ekonomi menandakan adanya peningkatan potensi PDB atau output suatu negara, pertumbuhan ekonomi suatu daerah dapat dihitung melalui indikator perkembangan PDB dari tahun ke tahun. Suatu perekonomian dikatakan baik apabila tingkat kegiatan ekonomi di masa sekarang lebih tinggi daripada yang sudah dicapai di masa sebelumnya. Antara tahun 1965 sampai 1997 perekonomian indonesia tumbuh dengan presentase rata-rata per tahunnya hampir 7 persen. Pencapaian ini memampukan perekonomian indonesia bertumbah dari peringkat "negara berpendapatan rendah" menjadi berpendapatan menengah ke bawah. Kendali begitu, krisis finansial Asia yang meletus pada akhir tahun 1990-an mengakibatkan dampak yang sangat negatif untuk perekonomian indonesia, menyebabkan penurunan produk domestik bruto (PDB) sebesar 13,6 persen pada tahun 1998 dan pertumbuhan yang terbatas pada 0,3 persen di tahun 1999.

Pertumbuhan ekonomi yang berkelanjutan adalah pertumbuhan yang ditopang oleh investasi, karena pertumbuhan ini dianggap akan dapat meningkatkan produktivitas sehingga membantu meningkatkan pertumbuhan ekonomi (Kuncoro, 2004). Investasi akan menambah jumlah (stock) dari kapital. di negara berkembang, terutama negara yang tingkat laju pertumbuhan penduduknya berada pada level tertinggi, kelebihan penawaran tenaga kerja adalah fitur umum.

Negara seperti ini biasa dikatakan negara dengan masalah ekonomi akut pengangguran. Ekstrimnya bahkan produktivitas marjinal mereka adalah nol bahkan minus. Selain iu, ada juga tenaga kerja yang tidak memiliki kualitas yang memadai, pada umumnya berkerja dengan menggunakan alat -alat tradisional yang tidak dapat meningkatkan produktivitas dibidang pertanian. Buta huruf membuat mereka mengalami kesulitan dalam menggarap ilmu dan teknologi yang baru. Sementara itu disisi lain pengenalan tekonologi baru di sektor industri, proses industri terkadang cendredung padat modal. Akibatnya pengangguran bertambah meskipun ada perbaikan disektor tertentu.

Menurut Smith (2006) pertumbuhan ekonomi merupakan suatu proses peningkatan kapasitas produktif dalam suatu perekonomian secara terus menerus atau berkesinambungan sepanjang waktu sehingga menghasilkan tingkat pendapatan dan output nasional yang semakin lama semakin besar. Tiga komponen pertumbuhan ekonomi yang penting bagi setiap masyarakat adalah (1) Akumulasi modal, termasuk di dalamnya semua investasi baru dalam bentuk tanah, peralatan fisik dan sumber daya 
manusia melalui perbaikan di bidang kesehatan, pendidikan dan keterampilan kerja, (2) Pertumbuhan jumlah penduduk yang pada akhirnya menyebabkan petumbuhan angkatan kerja, (3) Kemajuan teknologi yang secara luas diartikan sebagai cara baru dalam menyelesaikan pekerjaan.

Perkembangan pertumbuhan ekonomi di Indonesia selama lima tahun terakhir (2013 - 2017) menunjukkan keadaan yang kurang menggembirakan. Pada Tahun 2013 pertumbuhan ekonomi mencapai 5,86 persen pertahun dan mengalami penurunan menjadi 5,07 persen pertahun pada pada Tahun 2017.

Pencapaian tingkat pertumbuhan ekonomi seperti yang telah direncanakan atau diperkirakan dan keberhasilan mengurangi angka pengangguran serta penciptaan stabilitas harga umum merupakan suatu ukuran keberhasilan kebijakan perekonomian suatu negara. Oleh karena itu, setiap negara berusaha untuk mencapai tingkat pertumbuhan ekonomi yang optimal dengan berbagai melakukan kebijakan. Pencapaian tingkat pertumbuhan ekonomi yang diinginkan diantaranya ditentukan oleh sektorsektor penentu yang berperan penggerak pertumbuhan ekonomi.

Berdasarkan hal tersebut, penelitian ini bertujuan untuk menganalisis faktor-faktor penentu pertumbuhan ekonomi di Indonesia yang difokuskan kepada tiga faktor yaitu inflasi, investasi asing langsung dan pengeluaran pemerintah.

\section{METODE}

Jenis data yang digunakan dalam penelitian ini adalah data sekunder yaitu data yang diterbitkan atau digunakan oleh organisasi yang bukan pengolahnya (Amir, 2009). Data yang digunakan yaitu data runtut waktu (Time Series) merupakan sebuah kumpulan observasi terhadap nilai-nilai sebuah variabel dari beberapa periode waktu yang berbeda, seperti harian, mingguan, bulanan, kuartalan, dan tahunan (Gujarati, 2010). Data tersebut selama periode tahun 2000-2017 yang berupa data pertumbuhan ekonomi Indonesia, inflasi, foreign direct investment (FDI) dan pengeluaran pemerintah. Sumber data diperoleh dari Bank Indonesia (BI) dan Badan Pusat Statistik Indonesia (BPS).

Metode analisis yang digunakan dalam penelitian ini adalah metode analisis deskriptif dan kuantitatif. Teknik analisis yang digunakan dalam penelitian ini adalah analisis regresi linier berganda metode semi-log dengan persamaan sebagai berikut.

$\mathrm{PE}=\beta 0+\beta 1 . \mathrm{INF}+\beta 2 \cdot \mathrm{LOG}(\mathrm{FDI})+\beta 3 \cdot \mathrm{LOG}(\mathrm{PP})+\mathrm{e}$

Dimana

$\beta 0:$ Konstanta

$\beta 1$ : Koefisien Inflasi

$\beta 2$ : Koefisien Foreign direct investment

$\beta 3$ : Koefisien Pengeluaran pemerintah

PE : Pertumbuhan Ekonomi

INF : Inflasi

FDI : Foreign Direct investment

PP : Pengeluaran Pemerintah

e : Error (Variabel Pengganggu)

\section{HASIL DAN PEMBAHASAN}

\section{Pertumbuhan ekonomi di Indonesia}

Pertumbuhan ekonomi adalah proses perubahan kondisi perekonomian suatu negara secara berkesinambungan menuju keadaan yang lebih baik selama periode tertentu. Pertumbuhan ekonomi dapat diartikan juga sebagai proses kenaikan kapasitas 
produksi suatu perekonomian yang diwujudkan dalam bentuk kenaikan pendapatan nasional.

Pertumbuhan ekonomi selalu berubah dari tahun ke tahun, perubahan tersebut disebabkan oleh berbagai macam faktor yang mempengaruhi. Secara terperinci pertumbuhan ekonomi Indonesia selama periode Tahun 2000 - 2017 dapat dilihat pada Tabel 2.

Tabel 2. PDB dan pertumbuhan ekonomi Indonesia, tahun 2000-2017

\begin{tabular}{ccc}
\hline Tahun & PDB(Miliar Rupiah) & Pertumbuhan Ekonomi(\%) \\
\hline 2000 & 1.389 .769 & 4,20 \\
2001 & 1.442 .984 & 3,83 \\
2002 & 1.505 .216 & 4,31 \\
2003 & 1.577 .171 & 4,78 \\
2004 & 1.656 .516 & 5,03 \\
2005 & 1.750 .815 & 5,69 \\
2006 & 1.847 .126 & 5,50 \\
2007 & 1.964 .327 & 6,35 \\
2008 & 2.082 .456 & 6,01 \\
2009 & 2.178 .850 & 4,63 \\
2010 & 2.313 .838 & 6,20 \\
2011 & 2.464 .566 & 6,51 \\
2012 & 2.616 .938 & 6,18 \\
2013 & 2.770 .345 & 5,86 \\
2014 & 2.909 .181 & 5,01 \\
2015 & 3.051 .040 & 4,88 \\
2016 & 3.204 .066 & 5,02 \\
2017 & 3.210 .494 & 5.07 \\
\hline
\end{tabular}

Sumber: Bank Indonesia, 2018 (diolah)

Berdasarkan Tabel 2 pertumbuhan ekonomi Indonesia mengalami fluktuasi, terjadinya naik turun tingkat pertumbuhan ekonomi Indonesia yang tidak stabil, dengan rata-rata perkembangannya sebesar 5,29 persen. pertumbuhan tertinggi terjadi pada tahun 2011 yaitu sebesar 6,51 persen, pertumbuhan tertinggi terjadi pada sektor impor barang dan jasa, yang mencapai 15,03 persen dan yang terendah adalah sektor pengeluaran konsumsi rumah tangga yang hanya mencapai 5,05 persen. Dan yang terendah terjadi pada tahun 2000 yaitu sebesar 4,20 persen ini merupakan pertumbuhan terendah dalam periode tersebut. Periode pemulihan dan percepatan pertumbuhan ekonomi yang mengesankan antara tahun 2000 dan 2011 itu terutama disebabkan oleh meningkatnya impor barang dan jasa dan ledakan harga komoditas pada tahun 2000-an.

Pada periode 2000-2005 nilai pertumbuhan ekonomi cenderung mengalami fluktuatif dengan rata-rata pertumbuhannya 4,64 persen, pertumbuhan tertinggi yang terjadi pada tahun 2000-2005 adalah tahun 2005 sebesar 5,69 persen meningkatnya laju pertumbuhan ekonomi Indonesia pada tahun 2005 dikarenakan terjadinya peningkatan yang sangat pesat pada sektor impor barang dan jasa. Dan pertumbuhan terendah pada periode 2000-2005 adalah di tahun 2001 yaitu sebesar 3,83 persen, rendahnya laju pertumbuhan ekonomi Indonesia pada tahun 2001 dikarenakan terjadinya penurunan yang sangat pesat pada sektor ekspor barang dan jasa.

Selanjutnya pada periode 2005-2009 nilai pertumbuhan ekonomi juga mengalami fluktuasi, dengan rata-rata pertumbuhannya sebesar 5,69 persen, pertumbuhan tertinggi yang terjadi pada periode 2005-2009 terjadi pada tahun 2007 sebesar 6,35 persen, hal itu dikarenakan meningkatnya laju pertumbuhan ekonomi pada sektor pembentukan 
modal tetap domestik bruto pada tahun tersebut. Dan pertumbuhan terendah pada periode tersebut terjadi pada tahun 2009 yaitu sebesar 4,63 persen hal itu disebabkan rendahnya sektor ekspor baang dan jasa. Pada periode 2009-2013 juga mengalami fluktuasi dengan nilai rata-rata 5,87 persen, yang mana pertumbuhan tertinggi terletak pada tahun 2011 yaitu sebesar 6,51 hal ini terjadi dikarenakan meningkatnya laju pertumbuhan ekonomi Indonesia pada sektor ekspor barang dan jasa.

Periode lima tahun terakhir 2013-2017 pertumbuhan ekonomi juga cenderung mengalami fluktuasi dengan nilai rata-rata 5,19 persen, yang mana laju pertumbuhan ekonomi Indonesia mengalami peningkatan yang sangat pesat pada tahun 2013 yaitu sebesar 5,86 hal ini terjadi dikarenakan meningkatnya laju pertumbuhan ekonomi Indonesia pada sektor pengeluaran konsumsi pemerintah yaitu sebesar 6,93 persen, dan pertumbuhan yang terendah lima tahun terakhir ini adalah pada tahun 2015 yaitu sebesar 4,88 persen, hal ini terjadi dikarenakan melemahnya laju pertumbuhan ekonomi Indonesia pada sektor ekspor barang dan jasa yaitu sebesar -1,97 persen.

\section{Perkembangan inflasi}

Tingkat inflasi adalah kenaikan persentase tahunan dalam tingkat harga umum yang diukur berdasarkan indeks harga konsumen atau indeks harga lainnya. Perkembangan inflasi di Indonesia dari tahun 2000-2017 dapat dilihat pada Tabel 3

Tabel 3. Perkembangan inflasi tahun 2000-2017

\begin{tabular}{ccc}
\hline Tahun & Inflasi $(\%)$ & Perkembangan(\%) \\
\hline 2000 & 9,3 & - \\
2001 & 12,55 & 34,95 \\
2002 & 10,03 & $-20,08$ \\
2003 & 5,06 & $-49,55$ \\
2004 & 6,40 & 26,48 \\
2005 & 17,11 & 167,34 \\
2006 & 6,60 & $-61,43$ \\
2007 & 6,59 & $-0,15$ \\
2008 & 11,06 & 67,83 \\
2009 & 2,78 & $-74,86$ \\
2010 & 6,96 & 150,36 \\
2011 & 3,97 & $-42,96$ \\
2012 & 4,30 & 8,31 \\
2013 & 8,38 & 94,88 \\
2014 & 8,36 & $-0,24$ \\
2015 & 3,35 & $-59,93$ \\
2016 & 3,02 & $-9,85$ \\
2017 & 3,61 & 19,54 \\
\hline Rata-rata & $\mathbf{7 , 1 9}$ & $\mathbf{1 4 , 7 5}$ \\
\hline
\end{tabular}

Sumber: Bank Indonesia, 2018 (diolah)

Tingkat inflasi di Indonesia mengalami fluktuasi secara terus menerus dengan rata-rata inflasi sebesar 7,19 persen. Tingkat inflasi tahun 2001 mencapai angka 12,55 persen, ini berarti lebih tinggi dibandingkan angka inflasi tahun sebelumnya yang hanya 9,3 persen. Tahun 2002 angka inflasi sebesar 5,2 persen. Komoditas yang memberi andil terbesar dalam inflasi pada tahun 2002 adalah tarif listrik sebesar 0,7 persen. Untuk tahun ini, BPS memperkirakan kenaikan harga bahan bakar minyak, tarif dasar listrik, dan tarif telefon akan memberi peningkatan angka inflasi sebesar dua persen.

Angka inflasi pada tahun 2002 itu menurun dari tahun sebelumnya, pada tahun 2001, angka inflasi tercatat sebesar 12,55 persen. Penurunan nilai tukar membuat tingkat inflasi sepanjang 2003 juga mengalami penyusutan, jika dibandingkan pada 
tahun 2002 tingkat inflasi menurun sebesar 4,97 persen. Selama 2003, suku bunga deposito juga menciut karena peningkatan likuiditas perbankkan. Sementara itu, tingkat suku bunga juga turun sebesar 4,62 persen dari tahun sebelumnya. Pada tahun 2004 tingkat inflasi Meningkat menjadi 6,40 persen lebih tinggi dibandingkan dengan tahun 2003 yang tingkat inflasinya hanya sebesar 4,97 pesen. Dengan adanya penyesuaian pada komponen administires prices, maka langkah yang ditempuh agar inflasi tetap terkendali adalah dengan menjaga stabilitas komponen pangan yang bergejolak.

\section{Perkembangan foreign direct investment (FDI)}

FDI adalah investasi dimana perusahaan multinasional membangun anak perusahaan mereka di Negara lain, yang menjadi tujuan ekspor untuk mempermudah kegiatan ekspor-impor dan juga menghemat biaya. Untuk melihat perkembangan Foreign direct investment dari tahun 2000-2017 dapat dilihat pada Tabel 4

Tabel 4. Perkembangan foreign direct investment (FDI), tahun 2000-2017

\begin{tabular}{ccc}
\hline Tahun & FDI (US\$) & Perkembangan (\%) \\
\hline 2000 & 15420 & - \\
2001 & 90275 & 9,02 \\
2002 & 97891 & 9,78 \\
2003 & 132072 & 13,20 \\
2004 & 102798 & 10,27 \\
2005 & 135793 & 13,57 \\
2006 & 156591 & 15,65 \\
2007 & 103414 & 10,34 \\
2008 & 148714 & 14,87 \\
2009 & 108153 & 10,81 \\
2010 & 162138 & 16,21 \\
2011 & 194745 & 19,47 \\
2012 & 245647 & 24,56 \\
2013 & 286175 & 28,61 \\
2014 & 28500 & 2,84 \\
2015 & 20054 & 2,00 \\
2016 & 39206 & 3,92 \\
2017 & 22028 & 2,12 \\
\hline
\end{tabular}

Sumber: Bank Indonesia , 2018 (diolah)

Perkembangan FDI di Indonesia selama periode 2000-2017 berfluktuasi, investasi asing yang tertinggi terjadi di Indonesia berada pada tahun 2013 yaitu sebesar 28,61 persen, sedangkan investasi asing terendah pada tahun 2017 yaitu sebesar 2,12 persen. Dengan jumlah nilai rata-rata sebesar 12,19 persen, Peningkatan FDI di Indonesia terutama terjadi setelah kuartal ketiga tahun 2000. Jumlah investasi yang masuk ke Indonesia semakin besar dibandingkan dengan investasi yang keluar. Seperti yang telah disebutkan sebelumnya, bahwa peningkatan investasi yang masuk ke Indonesia disebabkan oleh adanya peningkatan pertumbuhan ekonomi di dalam negeri. Pertumbuhan ekonomi di Indonesia mempengaruhi jumlah investasi yang masuk ke Indonesia. Pada tahun 2000, pertumbuhan ekonomi mendorong peningkatan investasi mesuk ke Indonesia kondisi ini terus berlanjut sampai tahun 2006 dan sempat menurun pada tahun 2004 yaitu sebesar 102.798 US\$dengan perkembangannya 10,27 persen.Pada tahun 2007 tingkat investasi kembali menurun sebesar 103.414 juta US\$ dengan perkembangannya 10,34 persen, di tahun 2008 sempat meningkat, dan di tahun 
2009 tingkat investasi kembali lagi menurun dengan tingkat investasi sebesar juta 108.153 US\$ 10,81 persen.

\section{Perkembangan pengeluaran pemerintah}

Pengeluaran Pemerintah merupakan bagian dari kebijakan fiskal yaitu suatu tindakan pemerintah untuk mengatur jalannya perekonomian dengan cara menentukan besarnya penerimaan dan pengeluaran pemerintah setiap tahunnya, yang tercermin dalam dokumen Anggaran Pendapatan Belanja Negara (APBN) untuk nasional dan Anggaran Pendapatan Belanja Daerah (APBD) untuk daerah atau regional. Tujuan dari kebijakan fiskal ini adalah dalam rangka menstabilkan harga, tingkat output, maupun kesempatan kerja dan memacu atau mendorong pertumbuhan ekonomi. Untuk melihat perkembangan pengeluaran pemerintah dari tahun 2000-2017 dapat dilihat pada Tabel 5

Tabel 5 dapat dilihat bahwa pengeluaran pemerintah pada periode 2000-2017 mengalami fluktuasi. Dimana dalam beberapa tahun Indonesia cenderung mengalami peningkatan dan sesekali mengalami penurunan, dengan rata-rata perkembangan sebesar 15,93 persen. Peningkatan perkembangan tertinggi pengeluaran pemerintah pada periode tahun 2000-2017 terjadi pada tahun 2006 yaitu sebesar 30,21 persen, dan perkembangan pengeluaran pemerintah yang paling rendah yaitu pada tahun 2009 yaitu sebesar -4,90 persen. Minimnya belanja pemerintah menjadi penyabab utama perlambatan ekonomi, konsusmsi rumah tangga mengalami penurunan dan ini yang paling banyak mendorong perlambatan ekonomi.Selain itu, perlambatan yang signifikan terhadap konsumsi pemerintah, seperti belanja pemerintah pada tahun 2014 tercatat hanya tumbuh sebesar 7,67 persen merosot jika dibandingkan dengan tahun sebelumnya yang perkembangannya mencapai 10,67 persen, peranan belanja pemerintah kurang optimal dalam menggenjot pertumbuhan ekonomi.

Tabel 5. Perkembangan pengeluaran pemerintah, tahun 2000-2017

\begin{tabular}{|c|c|c|}
\hline Tahun & Pengeluaran Pemerintah (MilliarRp) & Perkembangan (\%) \\
\hline 2000 & 221467 & \\
\hline 2001 & 341565 & 54,22 \\
\hline 2002 & 322180 & $-5,67$ \\
\hline 2003 & 370565 & 15,01 \\
\hline 2004 & 427187 & 37,05 \\
\hline 2005 & 511619 & 19,76 \\
\hline 2006 & 666212 & 30,21 \\
\hline 2007 & 757650 & 13,72 \\
\hline 2008 & 985731 & 30,10 \\
\hline 2009 & 937382 & $-4,90$ \\
\hline 2010 & 1042117 & 11,17 \\
\hline 2011 & 1294999 & 24,26 \\
\hline 2012 & 1491410 & 15,16 \\
\hline 2013 & 1650564 & 10,67 \\
\hline 2014 & 1777183 & 7,67 \\
\hline 2015 & 1806515 & 1,65 \\
\hline 2016 & 1864275 & 3,19 \\
\hline 2017 & 2007351 & 7,67 \\
\hline
\end{tabular}

Sumber data: Bank Indonesia, 2018 (diolah)

Pengaruh inflasi, investasi asing langsung dan pengeluaran pemerintah terhadap pertumbuhan ekonomi Indonesia

Estimasi persamaan regresi pengaruh inflasi, investasi asing langsung dan pengeluaran pemerintah terhadap pertumbuhan ekonomi Indonesia diberikan pada Tabel 6 berikut: 
Tabel 6. Hasil regresi linier berganda metode semi-log

\begin{tabular}{ccccc}
\hline Variable & Coefficient & Std. Error & t-Statistic & Prob. \\
\hline C & -9.333514 & 3.405226 & -2.740938 & 0.0159 \\
INFLASI & 0.028499 & 0.039860 & 0.714980 & 0.4864 \\
LOG(FDI) & 0.502548 & 0.152789 & 3.289151 & 0.0054 \\
LOG(PP) & 0.638541 & 0.209870 & 3.042549 & 0.008 \\
\hline $\mathrm{R}^{2}=0.594$ & & & & \\
$\mathrm{~F}_{\text {hitung }}=6.844$ & & & & \\
$\mathrm{~F}_{\text {tabel }}=3.34$ & & & & \\
$\mathrm{~T}_{\text {tabel }}=1.753$ & & &
\end{tabular}

Sumber : Data diolah, 2018

\section{Uji multikolinearitas}

Uji multikolinearitas digunakan untuk melihat apakah didalam sebuah model regresi terdapat korelasi antar variabel bebas. Untuk mendeteksi adanya multikolinearitas dapat dilakukan pengujian dengan menggunakan VIF (Variance Inflantion Factors).

Tabel 7. Hasil uji multikolinearitas

\begin{tabular}{cccc}
\hline Variable & $\begin{array}{c}\text { Coefficient } \\
\text { Variance }\end{array}$ & $\begin{array}{c}\text { Uncentered } \\
\text { VIF }\end{array}$ & $\begin{array}{c}\text { Centered } \\
\text { VIF }\end{array}$ \\
\hline C & 11.59557 & 674.3085 & NA \\
INFLASI & 0.001589 & 5.664526 & 1.237344 \\
LOG(FDI) & 0.023345 & 176.4150 & 1.023555 \\
LOG(PP) & 0.044046 & 477.2504 & 1.211692 \\
\hline
\end{tabular}

Sumber : Data diolah, 2018

Diperoleh hasil nilai VIF untuk variabel inflasi, foreign direct investment (FDI) dan pengeluaran pemerintah masing-masing mendapatkan nilai 1,23, 1,02, 1,21. Karena nilai VIF dari ketiga variabel lebih kecil dari 10 maka dapat dinyatakan bahwa penelitian ini bebas dari gejala multikolinearitas

\section{Uji heteroskedastisitas}

Uji heteroskedastisitas digunakan untuk melihat ada atau tidaknya penyimpangan dari asumsi klasik. Heteroskedastisitas terjadi pada saat residual dan nilai prediksi memiliki korelasi atau pola hubungan. Uji heterokedastisitas model diberikan sebagai berikut:

Tabel 8. Hasil uji heteroskedastisitas

\begin{tabular}{|c|c|c|c|}
\hline \multicolumn{4}{|c|}{ Heteroskedasticity Test: White } \\
\hline F-statistic & 0.429617 & Prob. F(3,14) & 0.7350 \\
\hline Obs*R-squared & 1.517400 & Prob. Chi-Square(3) & 0.6783 \\
\hline Scaled explained SS & 0.929014 & Prob. Chi-Square(3) & 0.8184 \\
\hline
\end{tabular}

Sumber : Data diolah, 2018

Berdasarkan hasil data yang telah di uji dapat diketahui $\mathrm{p}$ Value yang ditunjuk dengan nilai prob.Chi-Square(3) pada Obs*R-squared yaitu sebesar 0.6783. Dengan nilai $\mathrm{p}$ value $0,6783>0,05(\alpha 5 \%)$ maka $H_{0}$ diterima yang berarti bahwa model regresi bersifat homoskedastisitas atau dengan kata lain model regresi terbebas dari gejala heteroskedastisitas dengan tingkat kepercayaan $95 \%$.

\section{Uji autokorelasi}

Uji ini digunakan untuk melihat ada atau tidaknya korelasi yang terjadi antara residual pada satu pengamatan dengan pengamatan lain pada model regresi. Untuk 
memastikan apakah model regresi linier terbebas dari autokorelasi, dapatmenggunakan metode Brusch-Godfrey atau LM (lagrange Multiplier) test dengan melihat nilai Prob.Chi-square, apabila besar dari 0,05 maka dapat dikatakan terbebas dari autokorelasi. Namun jika kecil dari 0,05 maka terjadi gejala auokorelasi

Tabel 9. Hasil uji autokorelasi

\begin{tabular}{lcll}
\hline Breusch-Godfrey Serial Correlation LM Test: & \\
\hline F-statistic & 0.527347 & Prob. F(2,12) & 0.6032 \\
Obs*R-squared & 1.454228 & Prob. Chi-Square(2) & 0.4833 \\
\hline
\end{tabular}

Sumber : Data diolah, 2018

Berdasarkan hasil regresi dapat diketahui bahwa nilai Pro.Chi-square(2) yang merupakan nilai $\mathrm{p}$ value dari uji Breusch-Godfrey serial Correlation LM Test, yaitu sebesar $0.4833>0,05(\alpha 5 \%)$ maka $H_{0}$ diterima atau dapat dikatakan bahwa dalam model ini tidak terdapat gejala autokorelasi

\section{$\underline{\text { Uji simultan (Uji F) }}$}

Nilai F-hitung adalah sebesar 6,844 dengan probabilitas sebesar 0,004540. Dengan probabilitas $<0,05(5 \%)$ maka $H_{0}$ di tolak. Maka, dapat disimpulkan bahwa inflasi, FDI dan pengeluaran pemerintah secara bersama-sama (simultan) berpengaruh dan signifikan terhadap pertumbuhan ekonomi Indonesia

Koefisien determinasi $\left(\boldsymbol{R}^{2}\right)$

Nilai $R^{2}$ sebesar 0,594602 , artinya, sebesar 59,46\% variabel dependen yaitu pertumbuhan ekonomi dipengaruhi oleh variabel independen yaitu inflasi, foreign direct investment dan pengeluaran pemerintah. Sedangkan sisanya sebesar $40,54 \%$ di pengaruhi oleh variabel lain yang tidak termasuk dalam penelitian ini.

\section{Uji parsial (uji t)}

Berdasarkan uji parsial (uji t) menunjukkan bahwa inflasi tidak berpengaruh signifikan terhadap pertumbuhan ekonomi Indonesia (probabilitas $=0.4864$ ). Sebaliknya, variabel foreign direct investment (FDI) berpengaruh signifikan terhadap pertumbuhan ekonomi Indonesia. Hal ini ditunjukkan dengan nilai probabilitas $0.0054<\alpha=5 \%$. Koefisien regresi foreign direct investment (FDI) sebesar 0,00000502 artinya jika variabel foreign direct investment (FDI) naik sebesar 1 Juta US\$ maka pertumbuhan ekonomi akan bertambah sebesar 0,00000502\%.

Variabel pengeluaran pemerintah berpengaruh signifikan terhadap pertumbuhan ekonomi Indonesia. Hal ini ditunjukkan dengan nilai probabilitas $0,049<\alpha=5 \%$. Koefisien regresi pengeluaran pemerintah sebesar 0,000000638 artinya jika variabel pengeluaran pemerintah naik sebesar 1 Miliar rupiah maka pertumbuhan ekonomi akan bertambah sebesar $0,000000638 \%$.

\section{KESIMPULAN DAN SARAN}

\section{Kesimpulan}

Secara keseluruhan dapat dilihat bahwa perkembangan inflasi dan FDI berfluktuasi dengan rata-rata perkembangan inflasi sebesar 14,74 persen dan perkembangan FDI sebesar 12,19 persen, sementara pertumbuhan ekonomi meningkat dan relatif stabil dengan rata-rata perkembangannya sebesar 5,29 persen, pengeluaran pemerintah meningkat dan relatif stabil dengan rata-rata perkembangannya 15,93.

Inflasi tidak berpengaruh signifikan terhadap pertumbuhan ekonomi Indonesia, sedangkan variabel foreign direct investment (FDI) dan pengeluaran pemerintah positif dan signifikan terhadap pertumbuhan ekonomi Indonesia. 


\section{Saran}

Pemerintah diharapkan dapat memprioritaskan anggaran belanja untuk pembangunan infrastruktur yang dapat meningkatkan investasi untuk mendorong pertumbuhan ekonomi dengan peningkatan ketersediaannya infrastruktur dapat menarik minat dalam berinvestasi.

Bagi pihak akademis disarankan jika akan meneliti lebih lanjutmengenai penelitian ini hendaknya dikaji lebih mendalam lagi, serta juga melihat variabel-variabel yang lain agar mendapat hasil yang lebih baik.

\section{DAFTAR PUSTAKA}

Amir, A. (2007). Perekonomian Indonesia dalam Perspektif Makro. Biografika: Bogor.

Amir, A, dkk.(2009). Metodelogi Penelitian Ekonomi dan Penerapannya. IPB Press: Jambi.

Ariefiando, M,D. (2012). Ekonometrika esensi dan aplikasi dengan menggunakan Eviews. PT gelora aksara pratama, Erlangga: Jakarta.

Delis.A., Candra.M., Etik, U. (2015)Pengaruh FDI terhadap Kemiskinan dan Pengangguran di Indonesia 1993-2013, Jurnal Paradigma Ekonomika. 10(1), 231-245

Desnky. R, Syaparuddin, Siti.A.(2018) Ekspor kopi Indonesia dan faktor-faktor yang mempengaruhinya, Jurnal Perdagangan, Industri dan Moneter, 6(1),23-34

Firdaus, M. (2011). Ekonometrika Suatu Pendekatan Aplikatik ( Edisi Kedua). Bumi Aksara: Jakarta.

Gujarati,D.N, Porter,DC. (2010). Dasar-dasar Ekonometrika (Edisi 5 Buku 1). Salemba Empat: Jakarta

Gujarati,D,N, Porter,DC. (2012). Dasar-dasar Ekonometrika (Edisi 5 Buku 2). Salemba Empat: Jakarta.

Mankiw. (2003). Makro Ekonomi Edisi Keenam. Erlangga: Jakarta.

Murni, A. (2009). Ekonomika Makro. PT Rafika adi tama: Bandung.

Priadi, S. (2008).Cadangan Devisa Financial Deeping, danStabilisasi Nilai Tukar Riil Rupiah Akibat Gejolak Nilai Tukar Perdagangan.Buletin Ekonomi Moneter dan Perbankan, Bank Indonesia, 11(2), 121-153.

Riani.E., Haryadi, Amril.(2014).Faktor Penentu Pertumbuhan Ekonomi Kabupaten Bungo. Jurnal Perspektif Pembiayaan dan Pembangunan Daerah, 2(1), 21-28

Sukirno, S.(2004).Pengantar Ilmu Ekonomi Makro. PT. RajaGrafindo Persada: Jakarta Syaifuddin, Adi.B, Rahma.N.(2017).Dampak Peningkatan Pengeluaran Konsumsi Sektor Rumah Tangga dan Pengeluaran Sektor Pemerintah Terhadap Pertumbuhan Ekonomi di Propinsi Jambi. Jurnal Sains Sosio Humaniora. 1(1), 66-78 